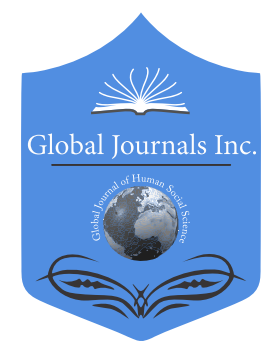

GLOBAL JOURNAL OF HUMAN-SOCIAL SCIENCE: G

LINGUISTICS \& EDUCATION

Volume 21 Issue 6 Version 1.0 Year 2021

Type: Double Blind Peer Reviewed International Research Journal

Publisher: Global Journals

Online ISSN: 2249-460X \& Print ISSN: 0975-587X

\title{
Obstacles of Teaching English as a Second Language in India
}

By Rinku Nandi

Abstract- Without language, we cannot imagine our society. The English language acts as a spinal cord in our modern India though English is a second language. Indians face many obstacles to teach English as a second language on Indian soil. This paper tries to capture the problems in its limited way, and accept the English language as a gift.

Keywords: India, English, second, obstacle, language.

GJHSS-G Classification: FOR Code: 200303

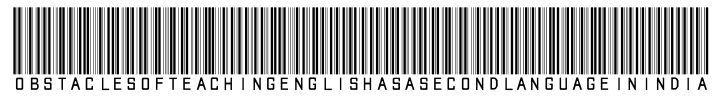

Strictly as per the compliance and regulations of:

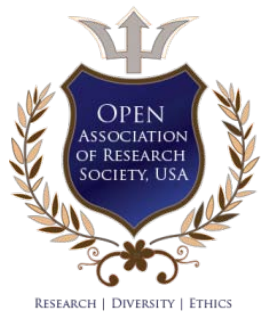

(c) 2021. Rinku Nandi. This is a research/review paper, distributed under the terms of the Creative Commons AttributionNoncommercial 3.0 Unported License http://creativecommons.org/licenses/by-nc/3.0/), permitting all non-commercial use, distribution, and reproduction in any medium, provided the original work is properly cited. 


\title{
Obstacles of Teaching English as a Second Language in India
}

\author{
Rinku Nandi
}

Abstract- Without language, we cannot imagine our society. The English language acts as a spinal cord in our modern India though English is a second language. Indians face many obstacles to teach English as a second language on Indian soil. This paper tries to capture the problems in its limited way, and accept the English language as a gift.

Keywords: India, English, second, obstacle, language.

\section{INTRODUCTION}

I anguage is the gift of God in our social life. The relation between language and society is transparent, and we cannot express this relation in words. Language is a very crucial medium of communication among society. We need to use language to fulfill our social needs. It is impossible to imagine the existence of a beautiful society without a language.

In this vast world, people use different languages in various ways. English is one of the most vital languages. We know India was a British Colony for a long time. But the position of English in India before independence and after independence was totally changed. During that colonial period, English was the language of the rulers. In India, the rulers took the initiative in teaching English among Indians to help their administrative and commercial fields. But Indians rejected the English language with their freedom in 1947. As English was banished from our social life, Hindi got the privilege. In this contrary situation, the importance of English is increasing day by day all over the world. Indians also felt the necessity for the English language. This scenario reveals to us that English was a foreign language in the colonial period. But gradually, English enjoyed the prestigious position of the second language in Indian social life.

A person's second language is that language that is not the mother-tongue of that person. English as a Second Language (ESL) is a popular term for using the English language by non-native speakers in prominent English countries where English is their mother-tongue. English as a second language reveals the language teaching for those persons whose primary language is not English. As a result, for those people, the position of English is either a second language or a foreign language. However, the English language is the gift for the Indians ------- the gift of the process of

Author: Assistant Teacher (P.G.) in English, Baidyadanga Girls' High School, Rasulpur, Burdwan. e-mail: missrinkunandi@gmail.com colonization. English language has great importance in India. Teaching English as a second language or a foreign language creates some problems on Indian soil. If we chalk out the whole situation, it is so pathetic to say that most of Indians cannot accept English freely. As a result, they felt uneasy in using English in our day-to-day life. There are many obstacles that subdue the process of teaching English as a second language in India.

Teaching English as a Second Language (ESL) or English as a Foreign Language (EFL) faces some hindrances in the Indian atmosphere.

\section{Excessive use of Mother-Tongue}

Indian students use excessive mother - tongue in a second language classroom teaching. When they learn English, i.e., second language, in a classroom situation, they are more interested to learn this through their mother-tongue. But they forget the original essence of the English language. They gave importance to their mother-tongue, not their second language. They sometimes use English words amid the sentences when they speak something in their mother - tongue. This mixture process creates only slow learners. So, most of the problem arises due to excessive use of mother tongue in English teaching.

This problem was solved when the teacher and student both love English though it is a second language. As a teacher, you translate the text English to English in a lucid way which attracts students to taste the original essence of the English language.

\section{il. Shortage of Time}

In India, time is one of the main obstacles to teach English as a second language. The duration of one class is 45 minutes. But the effective time of a teacher is 35 minutes. It is impossible to learn details of a vital subject like English in this short period. So teacher discusses only the main parts of the topic. We know that Good teaching is successful when there is some time for question-answer and feedback. But this process should not always be maintained only for that shortage of time. Sometimes we observe that teachers rush for the completion of exam syllabus only. As a result, students could not learn the second language in the proper way.

Time should be developed for better teaching, and better learning as English is the second language in India. 


\section{ImProper InfRASTRUCTURE}

School buildings, classrooms, laboratories, playgrounds, and libraries are the most significant part of school infrastructure. But in primary level to higherlevel schools suffer for improper infrastructure. But lack of proper grants, school authority cannot provide sufficient equipment for better teaching.

The proper infrastructure of schools should create an environment that not only assures teaching and learning but also pays attention to develop the mental level of the students. Poor infrastructure affects the psychology of a child. Sometimes we say school is our second home. Students need proper and wellequipped infrastructure for a homely atmosphere in schools.

\section{Crowded Classes}

The picture of a classroom means a large number of heterogeneous learners gathering in a class. Here the teacher-student ratio was not maintained. For this reason, individual attention is not possible in this short period. Sometimes crowded classes create a chaotic situations.

To avoid the excessive number of students in a class, we must divide the large class into small study groups. This process would be fruitful if the teacherstudent ratio was maintained. As a result, individual attention is possible in teaching English which is a vital point to overcome this problem.

\section{Lack of Attractiveness in the Classroom}

Today we see the same picture of the classroom in remote past that is chalk, duster, blackboard, etc. But we must remember the changing nature of time and the changing psychological level of a child. Lack of modern technology students lose their interest in studies.

An attractive classroom is an essential factor in teaching a second language or a foreign language. Our classroom is more attractive if we decorate our classroom with modern technological goods. An ideal classroom is a positive place where students peacefully take part in teaching English.

\section{Vi. Lack of Pronunciation}

Teacher and student both are social beings. As social beings, they have the effect of regional dialects and incorrect pronunciation. The causes of wrong pronunciation are substituting sounds from mothertongue and lack of proper knowledge in English subject. Another vital source is lack of knowledge of intonation and stress. In a sentence stressing the wrong word mar the originality of the English language that creates a funny situation sometimes.
In the English language, proper pronunciation is the master key. To overcome this problem when listening something, we must carefully observe the stress and intonation. A linguistic teacher should be avoided regional dialects. If we practice repeatedly and follow the proper stress and intonation, we must be successful.

\section{Vil. Confusion of Spoken and Written ENGLISH}

Confusion of spoken English is a common problem. Students listen and understand spoken English. Students think that they have a good level of knowledge in English. But reality reveals another fact. Students face many problems in speaking the English language. Most of the complications were -------

\section{A. Lack of confidence in speaking the English Language \\ B. Fear of making mistakes \\ C. Shyness in speaking the English Language \\ D. Feeling hesitant while speaking English.}

Even grammatical mistake in sentence formation is a vital problem teachers face in teaching the English language.

We must remember that the grammar part is just like the spinal cord in English sentence formation. A student should be more careful to learn grammatical rules and check the spelling before and after writing. Students learn more vocabulary to improve their speaking power in the English Language.

\section{Vili. Family BaCkground}

As we are a social human beings, our family plays an indirect role in our education system. After learning their second language, when they go back home, they are habituated to use their mother-tongue. So they have no scope to practice the second language. Even sometimes, we observe that maximum family members of some students are illiterate. So without practice, they forget their second language.

In the present-day the light of education removes the darkness. Students feel more energetic when their family supports for better education.

\section{iX. Wrong Examination System}

Examination means the assessment of a student's knowledge in a particular subject. The examination system is mainly based on theoretical papers. The practical papers are not emphasized perfectly. Many students pass the examination only memorizing the text. For that, they score good marks in the examination. Actually, the examination system has no scope to learn the mastery over the English language. 
The examination system has an important role in teaching English successfully. An ideal examination system means both teaching and learning. In the modern age, the examination system offers a chance to a mediocre student to show their skills in various fields. Analytical questions must be emphasized in the Indian examination system because these analytical questions can make students use his brain properly.

\section{Lack of Interest in the Subject}

As India is a multi-lingual country, students do not feel about learning the English language at the primary level. But when they understand the necessity of the English language for getting a better job ------- then they are too late to learn English properly. Family background, society, and education system are responsible for this negligible situation.

English is related to our day-to-day life though it is a second language. It is necessary to learn English at the primary level.

\section{Xi. Deny to use the Second Language for Communication}

In India, it is a noticeable issue that after learning the second language, students go back to their native language for communication. English language teachers observed the students who are so lazy to rethink and reword their thoughts into the new language.

Practice brings solutions for communicating in English. Good communicators listen carefully and then speak or write clearly. Good command of English helps us to improve our career and various fields in life as English is the international language.

\section{Xil. Limited Vocabulary}

In the English language, vocabulary is a very crucial part. If we express our thoughts in English, we must know the vocabulary. But some Indian students have limited vocabulary. For this reason, when they write something in English, they face a great problem. Poor vocabulary is a paramount obstacle in teaching English as a second language.

The solution of poor vocabulary is to develop the habit of reading English books, newspapers, magazines, etc. This habit of reading helps Indian students to improve their English skills.

\section{Xili. Improper Methodology}

In teaching English the methods, and techniques used by some teachers are backdated. The main part of the method is oral work which is neglected. Teachers used textbook translation which reduces the quality of good teaching.
A method is an umbrella term that includes within its periphery theoretical principles of language teaching and learning. Proper method enriches students' vocabulary and saves time in classroom teaching. Direct Method helps the students in fluent selfexpression and to develop the thinking power in English without the intervention of mother-tongue. The success of the method depends on the efficiency of the good teacher though in India, efficient teachers who have oral proficiency are rare.

\section{XiV. Insufficient Audio-Visual Aids}

Audiovisual aids are very important in the education system. But lack of money, school authority cannot provide sufficient audio-visual aids for better teaching in the English language. In this modern age, technology plays a huge role in our mind. Students want to use technology in their educational system.

Audio media is very helpful in developing the listening skills of students and stimulate the brain actively. Audio media supports distance learning courses and helps in the memorization process. Visual aids increase the retention level and student's interest in the subject and stimulate the student's vision. Audiovisual aids are used in classrooms to encourage the second language teaching-learning process, and the students feel the process very interesting. Audio-visual aids are the best process for second language teaching effective and develop the student's knowledge.

\section{Teacher's Failure to Create emotions in Students}

Emotion stimulates teaching-learning process. But some teachers fail to create emotions in the minds of the students. Teachers are always busy to complete the syllabus for the coming examination. They must remember that emotion and teaching-learning process are inseparable.

A new cognitive study reveals the mysterious role of emotions in education. Emotions can affect the learner's levels of motivation.

\section{Economic Background}

Economic background means the economic status of a family in society. Actually, economic background reveals the student's parent's educational qualifications, parent's occupations, and household income, etc. In our society economic background and student's academic performance are closely related. Poverty is a major economic issue. Due to poverty, some students are drop out of the regular education system. Lack of money poor students cannot continue higher education and face many obstacles in their teaching-learning process.

But our Government tries to solve this lower economic background. The government of India 
launched the Mid-Day-Meal Scheme in school meal programmes for student's better nutrition. The money from a scholarship helps students to continue higher education. Besides this, Government helps to provide Kanyashree Prakalpa, Sikshashree Scheme, Yuvashree Scheme, SabujSathi Scheme, etc. for the better educational programmes.

\section{XVil. Lack of Qualified Teachers in English}

The lack of qualified and sufficient English teachers is a vital issue in teaching obstacles in English as a second language in India. This shortage of qualified teachers in English is mainly observed in rural areas. Many qualified and experienced teachers prefer to teach in town areas for better facilities.

English teacher's professional qualifications must be developed to bridge the gap between the theory and practice for a better second language teaching process.

\section{XVili. Lack of Motivation}

Lack of Motivation is an important obstacle in teaching a second language. The student shows some negative attitudes towards the target language. The main reason is that students accepted the teachinglearning process as a burden. For this acceptance they are very lazy to know various sides of a second language.

But proper motivation can change a learner's mind. Motivation changes student's way of thinking and feeling. Encourage them to know English and motivated them to maintain a routine for better knowledge and better improvement in English.

India faces many problems in teaching English as a second language. Besides this, India realizes the importance of the English language. At the school level, the linguistic aims of teaching English are four-fold ------

A. To understand English when spoken --------- It helps to develop the listening skill in the students.

B. To speak English -------- It helps to improve speaking ability in the students in our day to day life.

C. To understand English when spoken ------ It improves reading ability.

D. To write English -------students should be able to write correct English without other's help.

To fulfill the aims and objectives of teaching English, some methods and approaches are designed. In India, Grammar Translation Method is the oldest method of teaching English. This method is applicable in a large class and quickly enriches students' vocabulary, and it saves time. Direct Method emphasizes to teach English in a natural setting, and it helps to develop good pronunciation and creative writing. Rabindranath Tagore's Method of teaching English is a very interesting method to the students as mother-tongue is the medium of instruction. It encourages students to know English through some play way method. Dr. West's New Method is a timesaving method as it develops the habit of silent reading. Structural Approach is very effective for second language teaching. The Functional Communicative Approach emphasizes students' activities based on reallife.

The English language dominates the modern world, and India realizes the importance of the English language though it is the second language in India. The English language helps us to see the modern world from a different perspective. This language will open the door in the various fields of knowledge.

At present time the scenario of our society completely changed. Indians felt the demand for the knowledge of English in our everyday life. So they want to overcome the obstacles in the paths of teaching English in India.

Now the educational system was controlled by English. In this globalization age, English achieves the prestigious official position. Not only that, English plays various roles amid Indian society. As a linking language English connects different people in various parts of the world. Indians accepted English in arts, science, technology, trade, commerce, law, medical science, engineering, agriculture, space research, etc. As an international language English language is the best gift for Indians to progress everywhere.

To conclude, through this paper, I discuss the problems which India faces in spreading the English language in India. This paper reveals the present situations in the process of teaching English in India. Indians not only learned the English language but also use it to create a new branch in literature named "Indian English Literature". English is not just a language --------- English language is the treasure for the modern Indian society. Indians tried to overcome all the hindrances and accepted the sweet fragrance of the English language. Actually, we realize the English language is the best gift of the colonization process. The contribution of a second language is an open window of knowledge and information in our modern lifestyle.

\section{ACKNOWLEDGEMENT}

The research article "Obstacles of Teaching English as a Second Language in India" has given me the golden opportunity for learning and selfimprovement. I consider myself lucky enough to have worked under Global Journal of Human Social Sciences. I am grateful to all the members of GJHSS.

I would like to express my special thanks and gratitude to my parents Krishna Chandra Nandi and Saraswati Nandi for their guidance and support in completing my paper. I would also like to thank Tinku Nandi (my sister) for her sincere help to enrich the article. 
I owe my gratitude to my trustworthy friend who is a doctor for his continuous support.

Last but not the least, I am grateful to all my family members and many well-wishers who helped me in numerous ways in concluding the article successfully.

\section{References Références Referencias}

1. Gangopadhyay, Anupama (Reprint - July 2010): Teaching of English, Kolkata, Rita Book Agency, pp.13, 19-21, 30-31, 77-104. 